\title{
SARS-CoV-2 Infection and ACE-2 Expression in Children: An Overview
}

\author{
Jayalakshmi Pandranki ${ }^{1}$, Jai Kiran Killada ${ }^{2}$, Maddula Madhavi Krishna ${ }^{3}$
}

\begin{abstract}
SARS-CoV-2 has marked a new era in the medical field with a wide array of signs and symptoms. The clinical manifestations may vary from simple sore throat to severe multiple organ failure causing death in adults. The severity of the disease was relatively mild in children compared to adults but the preliminary evidence reveals high proportions of asymptomatic infection which contributes to a viral transmission. It still remains ambiguous why children are less severely affected than adults. This literature provides a comprehensive review of epidemiology, vulnerability, pathophysiology, organ-specific systemic manifestations of coronavirus disease-2019 (COVID-19), its clinical course similarities and differences between child and adult with a special focus on the reasons behind the reduced disease severity in children.
\end{abstract}

Keywords: Angiotensin-converting enzyme 2, Clinical manifestations, Coronavirus disease-2019 in children, SARS-CoV-2.

International Journal of Experimental Dental Science (2021): 10.5005/jp-journals-10029-1218

\section{INTRODUCTION}

Severe acute respiratory syndrome (SARS) of viral origin (SARS coronavirus) was first reported in 2003 characterized by influenzalike symptoms. This coronavirus was uncertainly emerged from bats, transferred to humans, and burst as an epidemic affecting around 8,100 persons approximately. Appropriate traditional infection control practices brought the global outbreak to an end within a span of 8 months. The SARS has revisited (SARS-CoV-2) as a cluster of idiopathic pneumonia cases in the month of December 2019 in Wuhan, China. World Health Organization (WHO) has declared a novel coronal virus outbreak as Public Health Emergency of International Concern and was named coronavirus disease-2019 (COVID-19). It has rapidly spread globally affecting millions of people and still continues to spread rapidly around the world and became a pandemic.'

\section{Epidemiology}

A cumulative total of about 59.8 million people have been infected globally of which 1.4 million (3.4\%) deaths were reported. India has a cumulative total of over nine million cases, which accounts for $87.5 \%$ of all southeast Asian regions (Table 1). ${ }^{2}$ Coronavirus disease-2019, a highly infectious disease has been reported in all age groups of children including neonates making up to $1-5 \%$ of the total reported cases. Most of the children infected with SARS$\mathrm{CoV}-2$ presented mild symptoms or are asymptomatic, scarcely developed life-threatening disease. ${ }^{3}$ Ogimi et al. observed that young age, especially younger than school age, children with underlying disease and immunosuppression are the only predictors of disease severity in children. ${ }^{4}$

\section{Pathophysiology}

SARS-CoV-2 utilizes angiotensin-converting enzyme 2 (ACE-2) receptors present on the biciliated epithelial cells of human lungs. These ACE-2 receptors are also distributed along with the tissues of the gastrointestinal system (ileum), heart, kidney, urinary bladder, etc., and also on cells like dendritic cells, macrophages, vascular endothelial cells, etc. ${ }^{5,6}$ (Table 2). After the spike protein of SARSCoV-2 binds to ACE-2 receptors on the cell surface, the virus enters \begin{tabular}{l} 
1,2Department of Pedodontics and Preventive Dentistry, GITAM Dental \\
College and Hospital, Visakhapatnam, Andhra Pradesh, India \\
3Department of Paedodontics and Preventive Dentistry, Anil \\
Neerukonda Institute of Dental Sciences, Visakhapatnam, Andhra \\
Pradesh, India \\
Corresponding Author: Jayalakshmi Pandranki, Department of \\
Pedodontics and Preventive Dentistry, GITAM Dental College \\
and Hospital, Visakhapatnam, Andhra Pradesh, India, Phone: +91 \\
9912860194, e-mail: mds.deepthi@gmail.com \\
How to cite this article: Pandranki J, Killada JK, Madhavi Krishna M. \\
SARS-CoV-2 Infection and ACE-2 Expression in Children: An Overview. \\
Int J Experiment Dent Sci 2021;10(1):19-24. \\
Source of support: Nil \\
Conflict of interest: None \\
\hline \hline
\end{tabular}

the cell via proteolytic cleavage through endocytosis involving two proteases, the transmembrane protease serine 2 (TMPRSS2) and cathepsin L (CTSL). After invading, proinflammatory cytokine

Table 1: Confirmed cases and fatalities in the top 10 affected countries as of February $24,2021^{2}$

\begin{tabular}{llll}
\hline $\begin{array}{l}\text { Country/region/ } \\
\text { sovereignty }\end{array}$ & Confirmed cases & Fatalities & $\begin{array}{l}\text { Case fatality } \\
(\%)^{*}\end{array}$ \\
\hline US & $28,259,88$ & 502,594 & 17.7 \\
India & $11,016,434$ & 156,463 & 1.42 \\
Brazil & $10,257,875$ & 248,529 & 2.42 \\
United Kingdom & $4,146,756$ & 121,536 & 2.93 \\
Russia & $4,142,126$ & 82,666 & 1.99 \\
France & $3,689,534$ & 85,195 & 2.31 \\
Spain & $3,161,432$ & 68,079 & 2.15 \\
Italy & $2,832,162$ & 96,348 & 3.40 \\
Turkey & $2,655,633$ & 28,213 & 1.06 \\
Germany & $2,405,263$ & 68,785 & 2.86 \\
Colombia & $2,233,589$ & 59,118 & 2.65 \\
\hline
\end{tabular}

${ }^{*}$ Crude rates not adjusted for age, sex, existing comorbidities, etc. 
Table 2: COVID-19 systemic manifestations

\begin{tabular}{|c|c|c|c|}
\hline Type & Mechanism of injury & Features & Source \\
\hline $\begin{array}{l}\text { Pulmonary } \\
\text { manifestations }\end{array}$ & $\begin{array}{l}\text { Viral invasion through ACE-2 } \\
\text { in type I and II alveolar cells } \\
\text { - Proinflammatory cytokine } \\
\text { cascade reaction }\end{array}$ & $\begin{array}{l}\text { - } \text { Cough } \\
\text { - Dyspnea } \\
\text { - Hemoptysis } \\
\text { - Shortness of breath } \\
\text { - Sputum production }\end{array}$ & $\begin{array}{l}\text { - } \quad \text { Conti et al. } \\
\text { - } \quad \text { Li et al. } \\
\text { Meta-analysis by } \\
\text { - } \quad \text { Rodriguez-Morales et al. }{ }^{8} \\
\text { - } \quad \text { Yang et al. }{ }^{9} \\
\text { - } \quad \text { Cao et al. }{ }^{10}\end{array}$ \\
\hline $\begin{array}{l}\text { Gastrointestinal } \\
\text { manifestation }\end{array}$ & ACE-2 in Gl epithelial cells & $\begin{array}{l}\text { - Nausea } \\
\text { - Vomiting } \\
\text { - Diarrhea } \\
\text { - Abdominal pain }\end{array}$ & $\begin{array}{l}\text { - } \text { Wang et al..11 } \\
\text { - } \quad \text { Kopel et al. }{ }^{12} \\
\text { - } \quad \text { Chen et al. }{ }^{13}\end{array}$ \\
\hline Hepatic manifestation & $\begin{array}{l}\text { Virus entry through ACE-2 } \\
\text { on hepatic endothelial cells } \\
\text { Abnormal high serum levels } \\
\text { of cytokines (serum IL-1, } \\
\text { IL-6, IL-10, etc.) derange liver } \\
\text { chemistries. }\end{array}$ & $\begin{array}{l}\text { Increased serum levels of } \\
\text { - } \quad \text { Alanine transaminase (ALT) } \\
\text { - } \text { Aspartate transaminase (AST) } \\
\text { - Bilirubin } \\
\text { Decreased levels of serum albumin } \\
\text { Microvascular steatosis }\end{array}$ & $\begin{array}{l}\text { - Meta-analysis by Lippi } \\
\text { and Plebani }{ }^{14} \\
\text { - Duan et al. }{ }^{15}\end{array}$ \\
\hline $\begin{array}{l}\text { Cardiovascular } \\
\text { manifestations }\end{array}$ & $\begin{array}{l}\text { Viral invasion through ACE-2 } \\
\text { receptors in myocardial cells } \\
\text { Cytokine storm can lead to Stress- } \\
\text { induced cardiomyopathy } \\
\text { Hypoxemia can elevate calcium } \\
\text { ion influx further leads to cardiac } \\
\text { myocyte apoptosis }\end{array}$ & $\begin{array}{l}\text { - Cardiac arrhythmias } \\
\text { - Ventricular tachycardia/ventricular fibrillation } \\
\text { - Fulminating myocarditis } \\
\text { - Pericarditis } \\
\text { - Acute coronary syndrome } \\
\text { - Heart failure } \\
\text { - Cardiogenic shock } \\
\text { - Cardiac arrest } \\
\text { Elevated levels of cardiac markers like troponins }\end{array}$ & $\begin{array}{l}\text { Li et al. }{ }^{16} \\
\text { Zhou et al. }^{17}\end{array}$ \\
\hline Renal manifestations & $\begin{array}{l}\text { ACE-2 receptors are highly } \\
\text { expressed in proximal tubules } \\
\text { and urothelial cells of the } \\
\text { bladder } \\
\text { - Hypovolemia, } \\
\text { rhabdomyolysis, hypoxemia, } \\
\text { sepsis, septic shock in } \\
\text { critically ill patients } \\
\text { - Cytokine storm cause } \\
\text { multiorgan failure }\end{array}$ & Acute kidney failure & $\begin{array}{l}\text { - } \text { Zhou et al. }^{17} \\
\text { - } \\
\text { - } \\
\text { - } \\
\text { et ang et al. } .^{13}\end{array}$ \\
\hline $\begin{array}{l}\text { Central nervous sys- } \\
\text { tem manifestations }\end{array}$ & ACE-2 receptors on dendritic cells & $\begin{array}{l}\text { - Headache } \\
\text { - Confusion } \\
\text { - Reduced levels of consciousness } \\
\text { - Dizziness } \\
\text { - Encephalopathy, meningitis } \\
\text { - Agitation } \\
\text { - Seizure } \\
\text { - Cerebral venous sinus thrombosis/cerebral } \\
\text { - } \text { hemorrhage }\end{array}$ & $\begin{array}{l}\text { Mao et al. }{ }^{19} \\
\text { Poyiadji et al. }{ }^{20} \\
\text { Wang et al. }^{11}\end{array}$ \\
\hline
\end{tabular}




\begin{tabular}{|c|c|c|c|}
\hline Type & Mechanism of injury & Features & Source \\
\hline $\begin{array}{l}\text { Peripheral nervous } \\
\text { system manifestations }\end{array}$ & ACE-2 receptors on dendritic cells & $\begin{array}{ll}\text { - Hypogeusia } \\
\text { - Hyposmia, polyneuropathy } \\
\text { - Neuralgia }\end{array}$ & $\begin{array}{l}\text { Mao et al. }{ }^{19} \\
\text { Cui et al. }{ }^{21} \\
\text { Villalba et al. }^{22}\end{array}$ \\
\hline $\begin{array}{l}\text { Hematological } \\
\text { manifestations }\end{array}$ & $\begin{array}{l}\text { ACE- } 2 \text { receptors on vascular } \\
\text { endothelial cells }\end{array}$ & $\begin{array}{l}\text { - Petechiae } \\
\text { - Systemic vasculitis (Kawasaki) }\end{array}$ & Xu et al. ${ }^{23}$ \\
\hline Ocular manifestations & $\begin{array}{l}\text { Neurotropic and mucotropic } \\
\text { effects }\end{array}$ & $\begin{array}{l}\text { - Chemosis } \\
\text { - Epiphora } \\
\text { - Conjunctival congestion } \\
\text { - Conjunctivitis }\end{array}$ & $\begin{array}{l}\text { Qing et al. }{ }^{24} \\
\text { Ma et al. }{ }^{25}\end{array}$ \\
\hline $\begin{array}{l}\text { Cutaneous } \\
\text { manifestations }\end{array}$ & $\begin{array}{l}\text { Neurotropic and mucotropic } \\
\text { effects }\end{array}$ & $\begin{array}{l}\text { - Erythematous rash } \\
\text { - Vesicular lesions } \\
\text { - Urticaria most commonly on the trunk, which } \\
\text { resolved within few days }\end{array}$ & $\begin{array}{l}\text { Recalcati }^{26} \\
\text { Tang et al. }^{27}\end{array}$ \\
\hline Oral manifestations & $\begin{array}{l}\text { Neurotropic and mucotropic } \\
\text { effects }\end{array}$ & $\begin{array}{l}\text { - } \text { Sore throat } \\
\text { - Unspecific oral ulcerations petechiae } \\
\text { - Geographic tongue } \\
\text { - } \text { Gysgeusia } \\
\text { - Opportunistic infections like } \\
\text { - Candidiasis } \\
\text { - Oral thrush } \\
\text { - Recurrent oral herpes simplex virus (HSV-1) } \\
\text { infection, etc. }\end{array}$ & $\begin{array}{l}\text { Xu et al. }{ }^{28} \\
\text { Lovato et al. }^{29} \\
\text { Sabino-Silva et al. }{ }^{30} \\
\text { Dziedzic and Wojtyczka }{ }^{31} \\
\text { Yuen et al. }{ }^{32} \\
\text { Amorim Dos Santos et al. }{ }^{33}\end{array}$ \\
\hline
\end{tabular}

cascade is initiated with increased levels of IL-1 $\beta$, IL- 6 , TNF, etc. resulting in a cytokine storm. ${ }^{7,34}$ The incubation period observed has been ranged between 2 days and 14 days. ${ }^{5}$

Viral mRNA replicates and produces new viral particles contributing to the viral load and secreted in tears, saliva, feces, etc. ${ }^{35}$ Real-time polymerase chain reaction (RT-PCR)/viral genome sequencing to detect 2019-nCoV nucleic acid is the main method of laboratory diagnosis. ${ }^{36}$ This can be tested using nasopharyngeal swabs, throat swabs, sputum, stool, or blood samples. Real-time polymerase chain reaction has revealed that there is no significant difference in the viral loads between young children and adults. Even a considerable percentage of pre- or mild-symptomatic carry viral loads likely to represent infectivity. ${ }^{37}$ False-negative results were frequently reported with a nucleic acid test in children. ${ }^{38}$

\section{Transmissibility}

In dentistry, salivary spatters or respiratory droplets infected with the virus can transmit the disease when they come in contact with conjunctival, nasal, or oral mucosa. ${ }^{39}$ Salivary glands in COVID-19 patients are the potential reservoir even in asymptomatic patients and hence infected saliva could be the source of infectivity. ${ }^{40}$ It can also occur through contaminated fomites as SARS-CoV-2 can reside on the surfaces for 72 hours. ${ }^{41} \mathrm{Xu}$ et al. observed long-lasting viral shedding in the fecal matter even after nasopharyngeal testing was negative, thus increasing the chances for feco-oral transmission. ${ }^{42}$ Coronavirus disease-2019 is a highly infectious disease, but the role of children in its transmission is still unclear. Children were more likely to be infected from a household contact with COVID19 adult patients.

\section{Systemic Manifestations}

The clinical manifestations are primarily related to the pulmonary system and its impact extends far beyond the respiratory system to other parts of the human body (Table 2). The symptoms of COVID19 are almost similar in children and adults, but the frequency of symptoms varies. Although the clinical findings in children are diverse, the most commonly reported symptoms are fever, cough, rhinitis, myalgia, sore throat, and headache and less commonly vomiting, abdominal pain, diarrhea, and febrile seizures. ${ }^{43}$ The recovery period was noticed within 1-2 weeks after the onset of the disease. ${ }^{44}$

Dong et al. $^{3}$ in their retrospective study observed that the clinical manifestations of COVID-19 infection in children were less severe than adults. However young children, especially infants are more vulnerable to COVID-19 infections. ${ }^{4}$ The clinical severities were stratified based on symptoms, laboratory abnormalities, chest imaging, and RT-PCR/genomic analysis in Table 3.

Laboratory findings display mostly normal leukocyte counts but few cases reported with lymphopenia and neutrophilia/ neutropenia. Thrombocytopenia may occur. Inflammatory markers like IL-6, C-reactive protein (CRP), and procalcitonin were found elevated in adults, ${ }^{45}$ but it is uncommon in children suggestive of the reduced inflammatory response to infection. ${ }^{42}$ Elevated levels of liver enzymes, lactate dehydrogenase, muscle enzymes, myoglobin, D-dimer, and abnormal coagulation might be seen in severe cases. ${ }^{36}$

\section{Multisystemic Inflammatory Syndrome}

Few children were reported with a multisystemic inflammatory condition similar to Kawasaki-a systemic vasculitis disease. It usually 
Table 3: COVID-19 staging of clinical severity in children

\begin{tabular}{|c|c|c|}
\hline Clinical severity according to Dong et al. ${ }^{3}$ & Proportion & Signs and symptoms \\
\hline Asymptomatic & $4.4 \%$ & - No clinical signs and symptoms, normal chest imaging. \\
\hline Mild & $51 \%$ & $\begin{array}{l}\text { - Fever, cough, sore throat, runny nose, sneezing, fatigue, and myalgia. } \\
\text { - Digestive symptoms, such as nausea, vomiting, abdominal pain, and diarrhea. } \\
\text { - Physical examination reveals congestion of the pharynx. } \\
\text { - No auscultatory abnormalities. }\end{array}$ \\
\hline Moderate & $38.7 \%$ & $\begin{array}{l}\text { - Pneumonia, frequent fever, and cough (mostly dry cough, followed by productive } \\
\text { cough). } \\
\text { - Wheezing, but no obvious hypoxemia (shortness of breath), snoring. } \\
\text { - Chest computed tomography shows subclinical lung lesions. (milder form of } \\
\text { ground-glass opacities). }\end{array}$ \\
\hline Severe & $5.3 \%$ & $\begin{array}{l}\text { - Fever, cough, diarrhea, dyspnea, central cyanosis, oxygen saturation }<92 \% \text {, } \\
\text { hypoxia. }\end{array}$ \\
\hline Critical & $0.6 \%$ & $\begin{array}{l}\text { - Acute respiratory distress syndrome, respiratory failure, shock, encephalopathy, } \\
\text { myocardial injury or heart failure, coagulation dysfunction, or acute kidney injury. }\end{array}$ \\
\hline
\end{tabular}

manifests itself 3-4 weeks after the child recovers from SARS-CoV-2 infection associated with elevated inflammatory markers. ${ }^{23}$

\section{Neurotropic and Mucotropic Effects of SARS-COV-2}

\section{Cutaneous Manifestations}

Exanthematous eruptions potentially related to SARS-CoV-2 infection are heterogeneous, widely distributed, and were primarily located on the trunk. They were detected during the prodromal or subclinical phase and mainly appeared as erythematous, urticarial, ${ }^{46}$ chickenpox-like/varicelliform-like vesicular lesions, ${ }^{47}$ petechiae rash, and also reactivation of herpes simplex virus 1 lesions were noticed. Vesicular lesions and peculiar (perniosis-like) skin lesions are few reported critical lesions. The latency period from systematic symptoms to exanthema has been ranged from 2 to 21 days. ${ }^{27,48}$

\section{Ocular Manifestations}

Ma et al. ${ }^{25}$ observed increased conjunctival discharge (55.1\%), yellow-green purulent discharge (22.4\%), white mucoid (18.4\%), or thin watery eyes (14.3\%), and with conjunctival congestion (10.2\%). Other ocular manifestation includes eye rubbing (38.8\%), ocular pain (8.2\%), eyelid swelling (8.2\%), tearing (4.1\%), and allergic conjunctivitis (4.1\%). Eye rubbing and conjunctival discharge were observed in children of all age groups, whereas tearing was only reported in children aged 1-5 years, and eyelid swelling was only recorded in children aged $10-16$ years. ${ }^{25}$ It is entirely conceivable that cough can lead to ocular infection through unavoidable handeye contact in children.

\section{Oral Manifestations}

Angiotensin-converting enzyme 2 receptors are also distributed in the oral tissues like the tongue, oral mucosa, salivary glands, etc. ${ }^{6,28}$ The susceptible tissues with these receptors can host SARS-CoV-2 virus can potentially affect the salivary gland function, olfactory disorders, taste disorders, and oral mucosal integrity due to certain neurotropic and mucotropic effects. ${ }^{29,30}$ The oral manifestations most commonly reported in adults include unspecific oral ulcerations, petechiae, geographic tongue, dysgeusia, gingivitis, etc. ${ }^{31}$ Acute COVID-19 infection with associated co-morbidities or intensive therapeutic measures might increase the susceptibility to various opportunistic infections like candidiasis, oral thrush, recurrent oral herpes simplex virus (HSV-1) infection, and fixed drug eruptions. ${ }^{30-32}$ Deterioration of systemic health with the impaired immune system may result in secondary lesions. ${ }^{33}$ There still exists a paucity of information regarding the oral manifestations in COVID19 positive children. But, it is always suggestive to be cautious during oral health examinations.

\section{Reasons behind Milder Course of COVID-19 in Children}

From the physiological point of view, COVID-19 in children have milder clinical course compared to adults could be due to the following reasons ${ }^{49-55}$

- The presence of more protecting cilia prevents the virus entry into the respiratory system. ${ }^{35,49}$

- Children have a weaker ability to trigger an acute inflammatory response to SARS-CoV-2. In contrast to adults, the coronavirus that infects children with common cold down-regulates the expression of ACE-2 receptors further reducing the expression of associate inflammatory modules. Hence, there is a reduced chance for initiation of "cytokine storm". 50,51

- In India, exposure to various vaccines as part of Universal immunization program [like Bacille Calmette-Guerin (BCG), influenza vaccine, etc.] may modulate the course of COVID-19 in children with protective immune response. ${ }^{52}$

- Less exposure to pollutants and lack of comorbidities that compromise lung function. ${ }^{53}$ These specific features can underestimate the rate of COVID-19 infected children.

- Expression of ACE-2 and TMPRSS2 is relatively low in children compared to adults, but the maturation of receptors may vary with age. ${ }^{54,55}$

- Viral interference: Children frequently exposed to more than one viral agents, thus adaptive immune response in children initiate an intriguing protective mechanism to lower respiratory tract infections. ${ }^{55}$

- Human T helper cells provide a protective benefit to children against COVID-19 via Th2 immune response. Th2 associated 
with allergic diseases in children dramatically reduced ACE-2 expression in the respiratory tract. Th2 cytokines drive also increases eosinophilic count which presents an unknown protective mechanism against SARS-CoV-2 infection. ${ }^{55}$

- Children have lower risk levels for developing acute respiratory distress syndrome due to decreased production of thrombin and fibrin. ${ }^{50}$

From the epidemiological perspective, the reason for the low prevalence rate in children could be due to under-sampling, underreporting of the disease, and also, not attending to schools could be a confounding factor. ${ }^{3}$

\section{Conclusion}

Globally, SARS-CoV-2 infection presented a milder course of disease in children to date. The disease severity in children differs from that of adults and the reasons behind it may be differential defense mechanism with trained immune response in children, low density of ACE-2 which provide a portal of entry for SARS-CoV-2, viral interference, and competition limiting the growth of SARS-CoV-2 and their limited ability to produce inflammatory cytokines. Even though children tend to have COVID-19 in milder/asymptomatic form, they have been found to harbor high levels of the virus and become silent carriers of the virus through nasopharyngeal secretions and even feces. Considering the risk of contagion, proper monitoring, early detection, and intervention, emphasis on infection control measures for infected children to reduce transmissibility and subsequently mitigate the pandemic.

\section{References}

1. WHO? Coronavirus Disease 2019 (COVID_19), Situation No. 51; 11th March, 2020.

2. Coronavirus COVI-19 Global Cases by the Centre for Systems Science and Engineering (CSSE) at Johns Hopkins University (JHU). Available from https://coronavirus.jhu.edu/map.html [Last accessed on 2021 Feb 24].

3. Dong Y, Mo X, Hu Y, et al. Epidemiology of COVID-19 among children in China. Pediatrics 2020;145(6):e20200702. DOI: 10.1542/peds.20200702.

4. Ogimi C, Englund JA, Bradford MC, et al. Characteristics and outcomes of coronavirus infection in children: the role of viral factors and an immunocompromised state. J Pediatr Infect Dis Soc 2019;8(1):21-28. DOI: 10.1093/jpids/pix093.

5. Ludvigsson JF. Systematic review of COVID-19 in children shows milder cases and a better prognosis than adults. Acta Paediatr 2020;109(6):1088-1095. DOI: 10.1111/apa.15270.

6. Zou X, Chen K, Zou J, et al. Single-cell RNA-seq data analysis on the receptor ACE2 expression reveals the potential risk of different human organs vulnerable to 2019-nCoV infection. Front Med 2020;14(2):185192. DOI: 10.1007/s11684-020-0754-0.

7. Li YC, Bai WZ, Hashikawa T. The neuroinvasive potential of SARS-CoV2 may play a role in the respiratory failure of COVID-19 patients. J Med Virol 2020;92(6):552-555. DOI: 10.1002/jmv.25728.

8. Rodriguez-Morales AJ, Cardona-Ospina JA, Gutiérrez-Ocampo E, et al. Clinical, laboratory and imaging features of COVID-19: a systematic review and meta-analysis. Travel Med Infect Dis 2020;34:101623. DOI: 10.1016/j.tmaid.2020.101623.

9. Yang J, Zheng Y, Gou X, et al. Prevalence of comorbidities in the novel Wuhan coronavirus (COVID-19) infection: a systematic review and meta-analysis. Int J Infect Dis 2020;94:91-95. DOI: 10.1016/j. ijid.2020.03.017.

10. Cao $Y$, Liu X, Xiong $L$, et al. Imaging and clinical features of patients with 2019 novel coronavirus SARS-CoV-2: a systematic review and meta-analysis. J Med Virol 2020;92(9):1449-1459. DOI: 10.1002/ jmv.25822.

11. Wang D, Hu B, Hu C, et al. Clinical characteristics of 138 hospitalized patients with 2019. novel coronavirus-infected pneumonia in Wuhan, China. JAMA 2020;323(11):1061-1069. DOI: 10.1001/jama.2020.1585.

12. Kopel J, Perisetti A, Gajendran M, et al. Clinical insights into the gastrointestinal manifestations of COVID-19. Digestive Dis Sci 2020;65(7):1932-1939. DOI: 10.1007/s10620-020-06362-8.

13. Chen L, Lou J, Bai Y, et al. COVID-19 disease with positive fecal and negative pharyngeal and sputum viral tests. Am J Gastroenterol 2020;115(5):790. DOI: 10.14309/ajg.0000000000000610.

14. Lippi G, Plebani M. Laboratory abnormalities in patients with COVID2019 infection. Clin Chem Lab Med 2020;58(7):1131-1134. DOI: 10.1515/ cclm-2020-0198.

15. Duan XF, Liu Z, Hao R, et al. The dynamic change of liver injury in patients with severe acute respiratory syndrome. Zhonghua Gan Zang Bing Za Zhi 2004;12(7):439.

16. Li B, Yang J, Zhao F, et al. Prevalence and impact of cardiovascular metabolic diseases on COVID-19 in China. Clin Res Cardiol 2020;109(5):531-538. DOI: 10.1007/s00392-020-01626-9.

17. Zhou F, Yu T, Du R, et al. Clinical course and risk factors for mortality of adult in patients with COVID-19 in Wuhan, China: a retrospective cohort study. Lancet 2020;395(10229):1054-1062. DOI: 10.1016/S01406736(20)30566-3.

18. Yang $X H$, Sun $R H$, Chen DC. Diagnosis and treatment of COVID-19: acute kidney injury cannot be ignored. Zhonghua Yi Xue Za Zhi 2020;100(16):1205-1208. DOI: 10.3760/cma.j .cn112137-20200229-00520.

19. Mao L, Jin $\mathrm{H}$, Wang $M$, et al. Neurologic manifestations of hospitalized patients with coronavirus disease 2019 in Wuhan, China. JAMA Neurol 2020;77(6):1-9. DOI: 10.1001/jamaneurol.2020.1127.

20. Poyiadji N, Shahin G, Noujaim D, et al. COVID-19-associated acute hemorrhagic necrotizing encephalopathy: CT and MRI features. Radiology 2020;296(2):E119-E120. DOI: 10.1148/radiol.2020201187.

21. Cui Y, Tian M, Huang D, et al. A 55-day-old female infant infected with COVID 19: presenting with pneumonia, liver injury, and heart damage. J Infect Dis 2020;221(11):1775-1781. DOI: 10.1093/infdis/jiaa113.

22. Villalba NL, Maouche Y, Ortiz MBA, et al. Anosmia and dysgeusia in the absence of other respiratory diseases: should COVID-19 infection be considered? Eur J Case Rep Intern Med 2020;7(4):001641. DOI: 10.12890/2020_001641.

23. Xu S, Chen M, Weng J. COVID-19 and Kawasaki disease in children. Pharmacol Res 2020;159:104951. DOI: 10.1016/j.phrs.2020.104951.

24. Qing H, Li Z, Yang Z, et al. The possibility of COVID-19 transmission from eye to nose. Acta Ophthalmol 2020;98(3):e388. DOI: 10.1111/ aos.14412.

25. Ma N, Li P, Wang $X$, et al. Ocular manifestations and clinical characteristics of children with laboratory-confirmed COVID-19 in Wuhan, China. JAMA Ophthalmol 2020;138(10):1-8.

26. Recalcati S. Cutaneous manifestations in COVID-19: a first perspective. J Eur Acad Dermatol Venereol 2020;34(5):e212-e213. DOI: 10.1111/ jdv.16387.

27. Tang K, Wang $\mathrm{Y}$, Zhang $\mathrm{H}$, et al. Cutaneous manifestations of the coronavirus disease 2019 (COVID-19): a brief review [published online ahead of print, 2020 May 7]. Dermatol Ther 2020(4):e13528. DOI: $10.1111 /$ dth. 13528

28. $\mathrm{Xu} \mathrm{H}$, Zhong L, Deng J, et al. High expression of ACE2 receptor of 2019 nCoV on the epithelial cells of oral mucosa. Int J Oral Sci 2020;12(8). DOI: $10.1038 / \mathrm{s} 41368-020-0074-x$

29. Lovato A, de Filippis C, Marioni G. Upper airway symptoms in coronavirus disease 2019 (COVID-19). Am J Otolaryngol 2020;41(3):102474. DOI: 10.1016/j.amjoto.2020.102474.

30. Sabino-Silva R, Jardim ACG, Siqueira WL. Coronavirus COVID-19 impacts to dentistry and potential salivary diagnosis. Clin Oral Investig 2020;24(4):1619-1621. DOI: 10.1007/s00784-020-03248-x.

31. Dziedzic A, Wojtyczka R. The impact of coronavirus infectious disease 19 (COVID-19) on oral health. Oral Dis 2021;27(Suppl 3):703-706. DOI: 10.1111/odi.13359. 
32. Yuen KS, Ye ZW, Fung SY, et al. SARS-CoV-2 and COVID-19: the most important research questions. Cell Biosci 2020;10(1):40. DOI: 10.1186/ s13578-020-00404-4.

33. Amorim Dos Santos J, Normando AGC, Carvalho da Silva RL, et al. Oral mucosal lesions in a COVID-19 patient: new signs or secondary manifestations? Int J Infect Dis 2020;97:326-328. DOI: 10.1016/j. ijid.2020.06.012.

34. Conti P, Ronconi G, Caraffa A, et al. Induction of pro-inflammatory cytokines (IL-1 and IL-6) and lung inflammation by coronavirus-19 (COVID-19 or SARS-CoV-2): anti-inflammatory strategies. J Biol Regul Homeost Agents 2020;34(2):327-331. DOI: 10.23812/CONTI-E.

35. Yuki K, Fujiogi M, Koutsogiannaki S. COVID-19 pathophysiology: a review. Clin Immunol 2020;215:108427. DOI: 10.1016/j. clim.2020.108427.

36. Chen ZM, Fu JF, Shu Q, etal. Diagnosis and treatment recommendations for pediatric respiratory infection caused by the 2019 novel coronavirus. World J Pediatr 2020;16(3):240-246. DOI: 10.1007/s12519020-00345-5.

37. Jones TC, Mühlemann B, Veith T, et al. An analysis of SARS-CoV-2 viral load by patient age. medRxiv 2020. DOI: 10.1101/2020.06.08. 20125484.

38. Zhou MY, Xie XL, Peng YG, et al. From SARS to COVID-19: what we have learned about children infected with COVID-19. Int J Infect Dis 2020;96:710-714. DOI: 10.1016/j.jijid.2020.04.090.

39. Peng X, Xu X, Li Y, et al. Transmission routes of 2019-nCoV and controls in dental practice. Int J Oral Sci 2020;12(1):1-6. DOI: 10.1038/s41368020-0075-9.

40. Xu J, Li Y, Gan F, et al. Salivary glands: potential reservoirs for COVID-19 asymptomatic infection. J Dent Res 2020;99(8):989. DOI: 10.1177/0022034520918518.

41. Van Doremalen N, Bushmaker T, Morris DH, et al. Aerosol and surface stability of SARS-CoV-2 as compared with SARSCoV-1. New Eng J Med 2020;382(16):1564-1567. DOI: 10.1056/NEJMc2004973.

42. XuY, Li X, Zhu B, et al. Characteristics of pediatric SARS-CoV-2 infection and potential evidence for persistent fecal viral shedding. Nat Med 2020;26(4):502-505. DOI: 10.1038/s41591-020-0817-4.

43. Zimmermann $P$, Curtis N. Coronavirus infections in children including COVID-19: an overview of the epidemiology, clinical features, diagnosis, treatment and prevention options in children. Pediatr Infect Dis J 2020;39(5):355-368. DOI: 10.1097/INF.0000000000002660.
44. Cao Q, Chen $Y$, Chen $C$, et al. SARS-CoV-2 infection in children: transmission dynamics and clinical charateristics. J Formos Med Assoc 2020;119(3):670-673. DOI: 10.1016/j.jfma.2020.02.009.

45. Henry BM, Lippi G, Plebani M. Laboratory abnormalities in children with novel coronavirus disease 2019. Clin Chem Lab Med 2020;58(7):1135-1138. DOI: 10.1515/cclm-2020-0272.

46. Henry D, Ackerman M, Sancelme E, et al. Urticarial eruption in COVID19 infection. J Eur Acad Dermatol Venereol 2020;34(6):e244-e245. DOI: $10.1111 / j d v .16472$.

47. Marzano AV, Genovese G, Fabbrocini G, et al. Varicella-like exanthem as a specific COVID-19-associated skin manifestation: multicenter case series of 22 patients. J Am Acad Dermatol 2020;83(1):280-285. DOI: 10.1016/j.jaad.2020.04.044.

48. Gianotti R, Veraldi S, Recalcati S, et al. Cutaneous clinicopathological findings in three COVID-19-positive patients observed in the metropolitan area of Milan, Italy. Acta Derm Venereol 2020;100(8):adv00124. DOI: 10.2340/00015555-3490.

49. Senthilkumaran S, Meenakshisundaram R, Shah S, et al. Coronavirus disease (COVID-19) in children: Indian perspectives. Indian Pediatr 2020;57(6):585-586. DOI: 10.1007/s13312-020-1869-8.

50. Balasubramanian S, Rao NM, Goenka A, et al. Coronavirus sisease 2019 (COVID-19) in children - what we know so far and what we do not Indian Pediatr 2020;57(5):435-442. DOI: 10.1007/s13312-020-1819-5.

51. Park JY, Han MS, Park KU, et al. First pediatric case of coronavirus disease 2019 in Korea. J Korean Med Sci 2020;35(11):e124. DOI: 10.3346/jkms.2020.35.e124.

52. Netea MG, Schlitzer A, Placek K, et al. Innate and adaptive immune memory: an evolutionary continuum in the host's response to pathogens. Cell Host Microbe 2019;25(1):13-26. DOI: 10.1016/j. chom.2018.12.006.

53. Yang J, Chen $Y, Y u Z$, et al. The influence of PM2.5 on lung injury and cytokines in mice. Exp Ther Med 2019;18(4):2503-2511. DOI: 10.3892/ etm.2019.7839.

54. Wang A, Chiou J, Poirion OB, et al. Single nucleus multiomic profiling reveals age-dynamic regulation of host genes associated with SARSCoV-2 infection. bioRxiv 2020. DOI: 10.1101/2020.04.12.037580.

55. Steinman JB, Lum FM, Ho PPK, et al. Reduced development of COVID19 in children reveals molecular checkpoints gating pathogenesis illuminating potential therapeutics. Proc Natl Acad Sci U S A 2020;117(40):24620-24626. DOI: 10.1073/pnas.2012358117. 